\section{Morphology-Dependent Titanium Dioxide Nanoparticle-Induced Keratinocyte Toxicity and Exacerbation of Allergic Contact Dermatitis}

\author{
Brian C Palmer ${ }^{1}$ and Lisa A De Louise ${ }^{1,2,3 *}$ \\ ${ }^{1}$ Department of Environmental Medicine, University of Rochester Medical
} Center, New York, USA

${ }^{2}$ Department of Biomedical Engineering, University of Rochester, Rochester, New York, USA

${ }^{3}$ Department of Dermatology, University of Rochester Medical Center, Rochester, New York, USA

\begin{abstract}
Titanium Dioxide $\left(\mathrm{TiO}_{2}\right)$ nanoparticles are commonly found in consumer products, such as sunscreens, and human dermal exposures are relatively high. Research suggests potential differences in the toxicity of anatase and rutile crystalline forms of $\mathrm{TiO}_{2}$. Additionally, transition metal dopants are frequently used to enhance physicochemical properties of $\mathrm{TiO}_{2}$ and the toxicity of these nanoparticles is not extensively studied. Therefore, this work examined the keratinocyte toxicity and in vivo skin allergy responses after treatment with $30 \mathrm{~nm}$ anatase, $30 \mathrm{~nm}$ rutile, or $<100 \mathrm{~nm}$ Mn-doped $\mathrm{TiO}_{2}$ nanoparticles. After a 24-hour exposure, there were no differences in keratinocyte cytotoxicity; however, $\mathrm{Mn}$-doped $\mathrm{TiO}_{2}$ nanoparticles induced significant in vitro ROS generation and in vivo skin swelling responses in a model of allergic contact dermatitis.
\end{abstract}

\section{Introduction}

Titanium dioxide crystalline particles have been used as food and consumer product colorants for decades [1]. The unique photochemical properties of $\mathrm{TiO}_{2}$ particles are also utilized in solar cells, water/air

*Corresponding author: Lisa A De Louise, Department of Environmental Medicine, University of Rochester Medical Center, New York, USA, Department of Biomedical Engineering, University of Rochester, Rochester, New York, USA, Department of Dermatology, University of Rochester Medical Center, Rochester, New York, USA Tel: +1 5852751810; Email: Lisa_DeLouise@urmc.rochester.edu

Citation: Palmer BC, De Louise LA (2020) Morphology-Dependent Titanium Dioxide Nanoparticle-Induced Keratinocyte Toxicity and Exacerbation of Allergic Contact Dermatitis. J Toxicol Cur Res 4: 019.

Received: June 30, 2020; Accepted: July 10, 2020; Published: July 17, 2020

Copyright: ( 2020 Palmer BC, et al. This is an open-access article distributed under the terms of the Creative Commons Attribution License, which permits unrestricted use, distribution, and reproduction in any medium, provided the original author and source are credited. remediation technologies, and sunscreens [2-6]. The two most common crystalline forms of $\mathrm{TiO}_{2}$ are anatase and rutile [7]. Furthermore, transition metal dopants, such as manganese, are commonly added during the $\mathrm{TiO}_{2}$ manufacturing process to modify physicochemical properties [8-13]. These occupationally relevant, metal-doped nanomaterials are not typically encountered outside of industrial settings. Alternatively, consumer dermal exposures to anatase and rutile $\mathrm{TiO}_{2}$ in sunscreens are relatively high [1]. The use of $\mathrm{TiO}_{2}$-based sunscreens was approved by the United States Food and Drug Administration (US FDA) in 1999 [14]. Modern inorganic ultraviolet light filters are nano-sized to provide a more attractive cosmetic appearance, compared to the opaque look of micron-sized particles. Due to increasing human exposures to $\mathrm{TiO}_{2}$ nanoparticles (NPs), research into the potential dermal toxicity of $\mathrm{TiO}_{2} \mathrm{NPs}$ has expanded.

Variations in the crystal structure of anatase and rutile $\mathrm{TiO}_{2} \mathrm{NPs}$ lead to differences in photochemical properties and cytotoxicity [7]. Multiple studies have observed increased cytotoxicity of anatase $\mathrm{TiO}_{2}$ NPs, compared to the rutile morphology $[15,16]$. Specifically, Sayes et al. [17], exposed human dermal fibroblasts to 3-5 nm anatase or rutile $\mathrm{TiO}_{2} \mathrm{NPs}$, and observed increased cytotoxicity in anatase treated samples [17]. These findings are often associated with increases in intracellular reactive oxygen species (ROS) production. Furthermore, the interaction of $\mathrm{TiO}_{2} \mathrm{NPs}$ with ultraviolet radiation increases ROS generation and leads to decreases in keratinocyte viability, which is often markedly higher in anatase $\mathrm{TiO}_{2}$-induced phototoxicity reactions [18-20]. While these observations are common in in vitro models, in vivo $\mathrm{TiO}_{2}$ dermal toxicity is less common, due to limited NP skin penetration [21-23]. Therefore, the uses of inorganic ultraviolet light filters are still recommended by most physicians and government agencies, despite the toxicological concerns surrounding $\mathrm{TiO}_{2}$ NPs [24].

There are relatively few studies examining $\mathrm{TiO}_{2}$ toxicity in both healthy skin and models of dermatitis. The skin barrier defect induced by irritant or allergic contact dermatitis could enhance NP interaction with viable skin cells and lead to dermal toxicity. Additionally, there are few toxicological studies of topically applied metal-doped $\mathrm{TiO}_{2}$ NPs, which may be relevant for occupational exposures. Previously, our lab has observed exacerbation of 2, 4-dinitrofluorobenzene induced ear swelling responses after topical application of Mn-doped $\mathrm{TiO}_{2}$ NPs [25]. The work presented here builds on those previous findings, and compares the keratinocyte toxicity and ear swelling responses of pure anatase, pure rutile, or $\mathrm{Mn}$-doped $\mathrm{TiO}_{2} \mathrm{NPs}$ in both in vitro and in vivo models.

\section{Results}

\section{$\mathrm{TiO}_{2}$ physical characterization}

The toxicities of anatase, rutile, or anatase dominant transition metal-doped $\mathrm{TiO}_{2} \mathrm{NPs}$ were compared in multiple in vitro and in vivo assays. The anatase and rutile $\mathrm{TiO}_{2} \mathrm{NPs}$ both had vendor reported physical diameters of $30 \mathrm{~nm}$. However, the hydrodynamic diameters of the anatase and rutile NPs were 
Citation: Palmer BC, De Louise LA (2020) Morphology-Dependent Titanium Dioxide Nanoparticle-Induced Keratinocyte Toxicity and Exacerbation of Allergic Contact Dermatitis. J Toxicol Cur Res 4: 019.

$1170 \pm 130.4$ and $474.5 \pm 8.2 \mathrm{~nm}$, respectively (Table 1). Hydrodynamic diameters were markedly higher than the reported physical dimensions, and the relatively high polydispersity indices suggest a high degree of agglomeration in the water dispersant. Similarly, evidence of possible agglomeration was observed for the $<100 \mathrm{~nm}$ manganese-doped $\mathrm{TiO}_{2} \mathrm{NPs}$ as previously reported [26]. All of the $\mathrm{TiO}_{2}$ NPs had negative zeta potentials in the water dispersant, and the measurements ranged from -9.05 to $-22.3 \mathrm{mV}$ (Table 1). While particle interactions visualized via TEM imaging after NP deposition and drying may not accurately reflect particle agglomeration in a dispersant, a high degree of particle co-localization was observed in TEM images (Figure 1). Furthermore, the primary NPs displayed variations in morphology (Figure 1 and Figure S1), but the primary sizes appeared close to vendor reported dimensions.

\begin{tabular}{|c|c|c|c|}
\hline Nanoparticle & $\begin{array}{c}\text { Hydrodynamic } \\
\text { Diameter }(\mathrm{nm})\end{array}$ & Polydispersity Index & $\begin{array}{c}\text { Zeta Potential } \\
(\mathrm{mV})\end{array}$ \\
\hline Mn Doped (A/R) & $556.40 \pm 33.36$ & 0.296 & $-9.05 \pm 1.16$ \\
\hline Anatase (A) & $1170 \pm 130.40$ & $0.95 \pm 0.06$ & $-14.2 \pm 0.75$ \\
\hline Rutile (R) & $474.47 \pm 8.18$ & $0.40 \pm 0.03$ & $-22.27 \pm 0.78$ \\
\hline
\end{tabular}

Table 1: $\mathrm{TiO}_{2}$ physical characterization by dynamic light scattering

Dilute dispersions of $\mathrm{TiO}_{2}$ nanoparticles in water were analyzed in a Malvern Zetasizer. The hydrodynamic diameter, polydispersity indices, and zeta potentials are all reported (mean $\pm \mathrm{SD}, \mathrm{n}=3$ ).
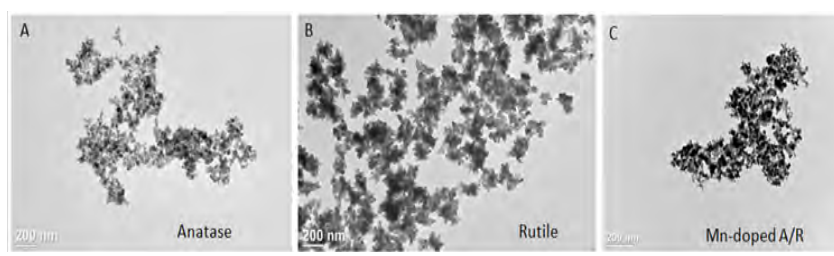

Figure 1: $\mathrm{TiO}_{2}$ physical characterization by TEM.

$\mathrm{TiO}_{2}$ nanoparticles were dispersed in acetone/water prior to deposition on grids for TEM analysis. The images of anatase (A), rutile (B), and $1 \% \mathrm{Mn}$ doped (C) particles show evidence for agglomeration. Scale bar $200 \mathrm{~nm}$

\section{$\mathrm{TiO}_{2}$ induced keratinocyte cytotoxicity and ROS generation}

HaCaTs are an immortalized human keratinocyte cell line that is commonly used for in vitro studies of skin toxicity or irritation. In all $\mathrm{TiO}_{2} \mathrm{NP}$ experiments, the particles were dispersed in water prior to addition to fetal bovine serum supplemented cell culture media. The cells were exposed to $0,5,10,50,100$, or $500 \mu \mathrm{g} / \mathrm{mL} \mathrm{TiO}_{2} \mathrm{NPs}$ for 24 hours, after which an ATP indicator was used to assess cell viability. Results show that a 24 hour exposure (Figure 2) the $\mathrm{TiO}_{2}$ NPs caused dose-dependent decreases in viability. The increased cytotoxicity became significant at $50 \mu \mathrm{g} / \mathrm{mL}$, and there was no observed difference in the cytotoxicity induced by anatase, rutile, or Mn-doped $\mathrm{TiO}_{2}$ NPs. Conversely, there were compositional-dependent differences in ROS generation, measured with a fluorescent ROS indicator, after 24 hours. While both pure anatase and rutile particles induced mild oxidative stress, the Mn-doped $\mathrm{TiO}_{2} \mathrm{NPs}$ markedly increased ROS generation at high-concentration exposures (Figure 3). To examine whether the increased ROS production observed at the 24-hour time point would induce a delayed cytotoxic response, a 48-hour cell viability assay was conducted. However, no differences in cytotoxicity were observed for any of the three $\mathrm{TiO}_{2}$ NPs tested (Figure S2). As mentioned previously, in vitro keratinocyte cytotoxicity could be indicative of potential dermal toxicity. Therefore, these $\mathrm{TiO}_{2} \mathrm{NPs}$ were exposed to murine skin in healthy or allergic contact dermatitis models.

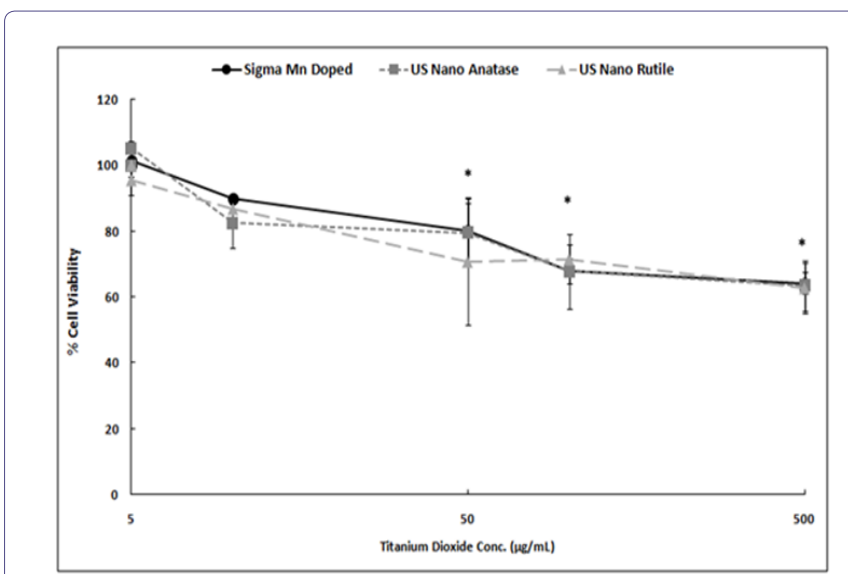

Figure 2: $\mathrm{TiO}_{2}$ induced keratinocyte cytotoxicity after 24 hours.

HaCaTs were exposed to $0,5,10,50,100$, or $500 \mu \mathrm{g} / \mathrm{mL}$ concentrations of anatase, rutile, or $1 \% \mathrm{Mn}$-doped $\mathrm{TiO}_{2}$ nanoparticles for 24 hours. Dose-dependent decreases in cell viability were observed for all $\mathrm{TiO}_{2}$ particles tested $($ mean $\pm \mathrm{SD}, \mathrm{n}=3)$.

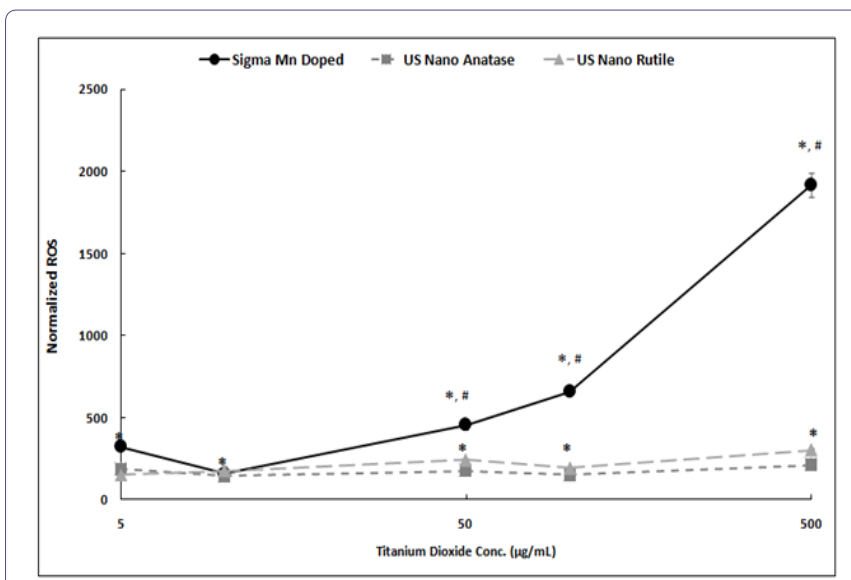

Figure 3: $\mathrm{TiO}_{2}$ induced keratinocyte ROS generation after 24 hours.

HaCaTs were exposed to $0,5,10,50,100$, or $500 \mu \mathrm{g} / \mathrm{mL}$ concentrations of anatase, rutile, or $1 \% \mathrm{Mn}$-doped $\mathrm{TiO} 2$ nanoparticles for 24 hours. While there were significant increases in ROS for all $\mathrm{TiO}_{2}$ nanoparticles, Sigma 1 $\%$ Mn-doped $\mathrm{TiO}_{2}$-induced ROS generation was markedly higher than either pure $\mathrm{TiO} 2 \mathrm{NP}($ mean $\pm \mathrm{SD}, \mathrm{n}=3)$.

\section{$\mathrm{TiO}_{2}$ exacerbation of DNFB-induced allergic contact dermatitis}

Our lab has previously observed the exacerbation of 2, 4-dinitrofluorobenzene (DNFB)-induced ear swelling in allergic contact hypersensitivity (CHS) mouse models after topical exposure to Mndoped $\mathrm{TiO}_{2}$ NPs [25]. To confirm that this effect occurs at concentrations that are relevant to human exposures, the ear swelling responses of all three $\mathrm{TiO}_{2} \mathrm{NPs}$ were examined in vivo. The allergic contact dermatitis mouse model consisted of topical DNFB exposures to hairless 
Citation: Palmer BC, De Louise LA (2020) Morphology-Dependent Titanium Dioxide Nanoparticle-Induced Keratinocyte Toxicity and Exacerbation of Allergic Contact Dermatitis. J Toxicol Cur Res 4: 019.

mice backcrossed onto C57BL/6 mice for 6 generations. The mice were sensitized with $0.05 \%$ DNFB on the dorsum five days prior to challenge with $0.2 \%$ DNFB on the ears. The right ears of each mouse were exposed to only DNFB, and the left ears were coexposed to DNFB plus $200 \mu \mathrm{g}$ of $\mathrm{TiO}_{2}$ NPs. Additionally, a set of mice received only vehicle to examine the effects of $\mathrm{TiO}_{2}$ NPs alone. The $200 \mu \mathrm{g}$ dose was selected based on current FDA recommendations for sunscreen application $\left(2 \mathrm{mg} / \mathrm{cm}^{2}\right)$ and a typical concentration of $\mathrm{TiO}$ in UVR filters in commercial sunscreens ( $10 \%$ by weight). Results showed there was no effect of the $\mathrm{TiO}_{2}$ NPs on ear swelling without DNFB, which indicates that these particles are not skin irritants. However, the Mn-doped $\mathrm{TiO}_{2}$ NPs significantly increased the level of DNFB-induced ear swelling (Figure 4) as previously observed, albeit as a different dose [25].

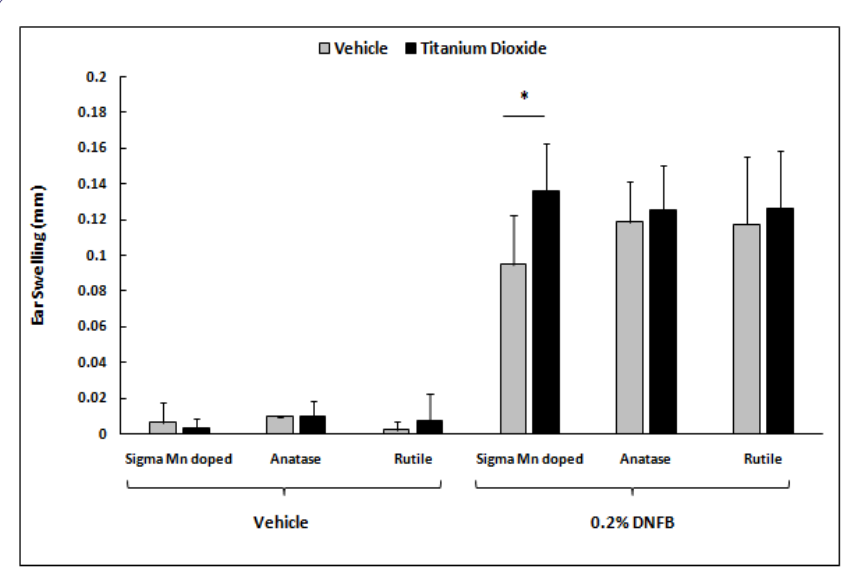

Figure 4: $\mathrm{TiO}_{2}$ exacerbation of DNFB-induced allergic contact dermatitis.

Mice were sensitized with $0.05 \%$ DNFB five days prior to challenge with either vehicle or $0.2 \%$ DNFB. For each mouse, the right ear was exposed to vehicle (gray bars) and the left ear was exposed to $200 \mu \mathrm{g}$ of $\mathrm{TiO}_{2}$ nanoparticles (black bars). After 24 hours, the $\mathrm{TiO}_{2}$ nanoparticles had no effect on skin swelling without DNFB challenge. However, Sigma Mn-doped $\mathrm{TiO}_{2}$ nanoparticles significantly increased DNFB-induced ear swelling (mean \pm $\mathrm{SD}, \mathrm{n}=3-6)$.

\section{Discussion}

In vitro exposures of $\mathrm{TiO}_{2} \mathrm{NPs}$ to a keratinocyte cell line led to dose-dependent decreases in cell viability that were not dependent on NP composition. Interestingly, the $\mathrm{Mn}$-doped $\mathrm{TiO}_{2} \mathrm{NPs}$ induced significantly more intracellular ROS generation than either pure $\mathrm{TiO}_{2}$ $\mathrm{NP}$ variants. These observations were indicative of potential dermal toxicity, but in vivo studies displayed no signs of $\mathrm{TiO}_{2} \mathrm{NP}$ skin irritation in the CHS model. However, Mn-doped $\mathrm{TiO}_{2} \mathrm{NPs}_{\text {did }}$ exacerbate skin swelling responses in a model of allergic contact dermatitis.

The allergic contact dermatitis response involves both innate and adaptive immune responses. Briefly, chemical haptens (such as DNFB) generate ROS and bind to proteins [27]. The ROS production is an important step in the activation of antigen presenting cells that express immune cytokines and present hapten-protein adducts $[28,29]$. This initial response is followed by mast cell degranulation and neutrophil influx to the skin [30,31]. Lastly, skin swelling and keratinocyte cell death occur in a cytotoxic and helper T cell-mediated manner [32-34]. While additional studies are required to elucidate the mechanism of action of Mn-doped $\mathrm{TiO}_{2} \mathrm{NP}$ exacerbation of allergic contact dermatitis, it is plausible that increases in intracellular ROS are involved. It is well established that Mn-induced neurotoxicity, commonly observed after occupational exposures, involves ROS generation [35]. Moreover, there is evidence of Mn hypersensitivity and irritation responses in skin patch tests [36,37]. Therefore, Mn ion dissolution and skin penetration is a plausible mechanism of action.

There was no $\mathrm{TiO}_{2}$ NP-induced skin irritation identified in this study, which is a finding similar to other reports of pure $\mathrm{TiO}_{2} \mathrm{NP}$ skin administration [38]. Additionally, there is no evidence in the literature of $\mathrm{TiO}_{2}$ NP-induced sensitization after topical administration [39], which is expected given the widespread use of $\mathrm{TiO}_{2} \mathrm{NPs}$ in consumer products. However, $\mathrm{TiO}_{2}$-related effects on allergic skin models have been reported. One set of studies in 2, 4-dinitrochlorobenzene-induced allergic contact dermatitis models displayed significant increases in sensitization potential, measured by local lymph node assays, after $\mathrm{TiO}_{2}$ subcutaneous or topical administration [40,41]. A second research group observed increases in skin lesion severity after intradermal injection of $\mathrm{TiO}_{2} \mathrm{NPs}(15,50$, or $100 \mathrm{~nm})$ in a mite allergen-induced mouse model of atopic dermatitis [42]. While the results presented here do not suggest allergic contact dermatitis exacerbation by pure $\mathrm{TiO}_{2}$ NPs, sensitization potentials were not studied. Additionally, discrepancies between these results could be explained by differences in particle morphology, dose, or animal model.

It remains unclear whether the in vivo effects of $\mathrm{Mn}$-doped $\mathrm{TiO}_{2}$ NPs are dependent on skin penetration. Some studies in mouse models report minimal $\mathrm{TiO}_{2} \mathrm{NP}$ skin penetration [43] and provided the skin barrier disruption that occurs during allergic contact dermatitis reactions [44], skin penetration is plausible. However, differences between mouse and human skin physiology, including thickness and hair follicle density, make interspecies comparisons difficult $[45,46]$. Future studies will include determination of both $\mathrm{Mn}$ ion release from the metal-doped $\mathrm{TiO}_{2} \mathrm{NPs}$ and $\mathrm{TiO}_{2} \mathrm{NP}$ penetration in mouse and human skin models.

Overall, the lack of observed in vivo dermal toxicity for pure anatase or pure rutile $\mathrm{TiO}_{2} \mathrm{NPs}$ is consistent with previously reported data. However, the $\mathrm{TiO}_{2}$ NPs tested here may not accurately reflect those found in consumer products and sunscreens. Therefore, additional studies examining $\mathrm{TiO}_{2} \mathrm{NPs}$ extracted from consumer products are warranted. Moreover, this work suggests that occupationally relevant, metal-doped $\mathrm{TiO}_{2} \mathrm{NPs}$ represent a greater health hazard and future research will examine not only mechanisms of action but also toxicities associated with $\mathrm{TiO}_{2}$ NPs doped with other commonly used transition metals.

\section{Methods}

\section{Particle Characterization}

Pure anatase (30 nm, $>99.9 \%$ purity, Cat\# US3498) or rutile (30 $\mathrm{nm},>99.9 \%$ purity, Cat\# US3520) titanium dioxide nanoparticles were purchased from US Research Nanomaterials, and an anatase dominant manganese-doped titanium dioxide $(<100 \mathrm{~nm}, 1 \% \mathrm{Mn}$ dopant, Cat\# 677469) nanoparticle was purchased from Sigma-Aldrich. The nanoparticles were dispersed in ultrapure water prior to physical characterization. The physical size and shape were qualitatively examined via TEM, and a Malvern Zetasizer was used to measure hydrodynamic diameters and zeta potentials. 
Citation: Palmer BC, De Louise LA (2020) Morphology-Dependent Titanium Dioxide Nanoparticle-Induced Keratinocyte Toxicity and Exacerbation of Allergic Contact Dermatitis. J Toxicol Cur Res 4: 019.

\section{DNFB and $\mathrm{TiO}_{2}$ in vitro exposure}

An immortalized keratinocyte cell line (HaCaTs) was grown in Dulbecco's Modified Eagle Medium (DMEM) (Gibco Cat\# 11965092) supplemented with $10 \%$ fetal bovine serum (Gibco Cat\# 10082147)/1\% penicillin/streptomycin (Gibco Cat\# 15140-122). The HaCaTs were seeded into 96-well plates and incubated in a $37^{\circ} \mathrm{C}$ and $5 \% \mathrm{CO}_{2}$ atmosphere. All analyses were conducted in cells in a logarithmic growth phase ( $70 \%$ confluence).

All cells were exposed to $0,5,10,50,100$, or $500 \mu \mathrm{g} / \mathrm{mL} \mathrm{TiO}_{2}$ for 24 or 48 hours. A Cell Titer-Glo assay (Promega Cat\# G7571), which includes a luminescent ATP indicator, was used to measure cell viability. Briefly, $50 \mu \mathrm{L}$ of CellTiter-Glo reagent was added to each well, and after 15 minutes the luminescence was measured with a Turner Biosystems Modulus microplate reader. For ROS measurements, the cells were incubated for 30 minutes in a $10 \mu \mathrm{M}$ solution of 2',7'-dichlorodihydrofluorescein diacetate (H DCFDA) (Thermo Fisher Scientific Cat\# D399) in sterile 1x phosphate buffered saline. After this pre-conditioning period, the cells were exposed to either vehicle or $\mathrm{TiO}_{2}$ for 24 hours. Conversion of $\mathrm{H}_{2}$ DCFDA to the fluorescent 2,7'-Dichlorofluorescein (DCF), an indicator of intracellular ROS, was measured on a fluorescence plate reader.

\section{DNFB and $\mathrm{TiO}_{2}$ in vivo exposure}

All in vivo experiments utilized an immunocompetent, hairless C57BL/6 mouse stain. These mice have a gene mutation that causes alopecia after the first follicular maturation. Therefore, these mice do not require potentially barrier disrupting depilation prior to topical exposures. Male mice between 5-6 months old were kept on a 12 hour light/dark cycle, and they were provided with food and water ad libitum throughout the study period. We have previously reported that DNFB reactions are age, but not sex-dependent $[25,47]$. On day 0 , mice were sensitized on the dorsum with $30 \mu \mathrm{L}$ of $0.05 \%$ DNFB (Sigma-Aldrich Cat\# D1529) in a 4:1 acetone/olive oil vehicle. Five days later, $20 \mu \mathrm{L}$ of $0.2 \%$ DNFB (with or without $200 \mu \mathrm{g} \mathrm{TiO}_{2}$ ) was applied to each ear, and increases in ear thickness were measured 24 hours post-challenge. A separate group of mice were challenged with vehicle (with or without $200 \mu \mathrm{g} \mathrm{TiO}_{2}$ ) to examine potential skin swelling effects of $\mathrm{TiO}_{2}$ alone. In vivo experiments were approved by the University Committee on Animal Resources (UCAR\#2010024/100360) at the University of Rochester Medical Center.

\section{Statistics}

All statistics were analyzed with JMP Pro version 13.2.1 (SAS Institute Inc., Cary, NC). All in vitro data were analyzed by a twoway analysis of variance with post-hoc Tukey tests. Alternatively, in vivo data were analyzed by a Student's T-test, since the ear swelling data compared only the right (DNFB challenged) and left (DNFB + $\mathrm{TiO}_{2}$ challenged) ears of each mouse. P-values $\leq 0.05$ were considered significant and represented by an * (significance compared to control) or \# (significance within a group). All data were presented as means \pm standard deviation.

\section{Acknowledgement}

We would like to thank Karen Bentley of the URMC electron microscope research core facility for help with NP TEM imaging. Additionally, we thank Ian Krout, Joseph Lucas, Jakob Gunderson, and Ashley Peppriell for technical assistance with the in vitro experiments. The work was supported by both the NIH NIEHS training grant ES07026 and the NIH NIEHS research grant RO1 ES021492.

\section{References}

1. Weir A, Westerhoff P, Fabricius L, Hristovski K, von Goetz N (2012) Titanium dioxide nanoparticles in food and personal care products. Environ Sci Technol 46: 2242-2250.

2. Bai Y, Mora-Seró I, De Angelis F, Bisquert J, Wang P (2014) Titanium dioxide nanomaterials for photovoltaic applications. Chemical Reviews 114: $10095-10130$

3. Vujovic M, Kostic E (2019) Titanium dioxide and zinc oxide nanoparticles in sunscreens: A review of toxicological data. Journal of cosmetic science 70: $223-234$

4. Dreno B, Alexis A, Chuberre B, Marinovich M (2019) Safety of titanium dioxide nanoparticles in cosmetics. J Eur Acad Dermatol Venereol 33: 3446 .

5. Sharma S, Sharma RK, Gaur K, Torres JFC, Loza-Rosas SA, et al. (2019) Fueling a hot debate on the application of $\mathrm{TiO}_{2}$ nanoparticles in sunscreen. Materials (Basel, Switzerland) 12: 2317.

6. Saqib NU, Adnan R, Shah I (2016) A mini-review on rare earth metal-doped $\mathrm{TiO}_{2}$ for photocatalytic remediation of wastewater. Environmental science and pollution research international 23: 15941-15951.

7. Luttrell T, Halpegamage S, Tao J, Kramer A, Sutter E, et al. (2014) Why is anatase a better photocatalyst than rutile?--Model studies on epitaxial $\mathrm{TiO}_{2}$ films. Sci Rep 4: 4043-4043.

8. Wang L, Fan J, Cao Z, Zheng Y, Yao Z, et al. (2014) Fabrication of predominantly $\mathrm{Mn}^{4+}$-doped $\mathrm{TiO} 2$ nanoparticles under equilibrium conditions and their application as visible-light photocatalyts. Chemistry, an Asian journal 9: 1904-1912.

9. Praveen P, Viruthagiri G, Mugundan S, Shanmugam N (2014) Sol-gel synthesis and characterization of pure and manganese doped $\mathrm{TiO}_{2}$ nanoparticles--a new NLO active material. Spectrochimica Acta. Part A: Molecular and Biomolecular Spectroscopy 120: 548-557.

10. Chauhan R, Kumar A, Chaudhary RP (2012) Structural and photocatalytic studies of $\mathrm{Mn}$ doped $\mathrm{TiO}_{2}$ nanoparticles. Spectrochimica Acta. Part A: Molecular and Biomolecular Spectroscopy 98: 256-264.

11. Xue, X, Ji W, Mao Z, Li Z, Ruan W, et al. (2012) Effects of Mn doping on surface enhanced Raman scattering properties of $\mathrm{TiO}_{2}$ nanoparticles. Spectrochimica Acta. Part A: Molecular and Biomolecular Spectroscopy 95: 213-217.

12. Shen B, Liu T, Zhao N, Yang X, Deng L (2010) Iron-doped Mn-Ce/TiO catalyst for low temperature selective catalytic reduction of $\mathrm{NO}$ with $\mathrm{NH}_{3}$. Journal of Environmental Sciences 22: 1447-1454.

13. Xu Y, Lei B, Guo L, Zhou W, Liu Y (2008) Preparation, characterization and photocatalytic activity of manganese doped $\mathrm{TiO}_{2}$ immobilized on silica gel. Journal of Hazardous Materials 160: 78-82.

14. United States Food and Drug Administration (2019) Washington D.C., USA.

15. De Matteis V, Cascione M, Brunetti V, Toma CC, Rinaldi R (2016) Toxicity assessment of anatase and rutile titanium dioxide nanoparticles: The role of degradation in different $\mathrm{pH}$ conditions and light exposure. Toxicol In Vitro 37: 201-210.

16. Turci F, Peira E, Corazzari I, Fenoglio I, Trotta M, et al. (2013) Crystalline phase modulates the potency of nanometric $\mathrm{TiO}_{2}$ to adhere to and perturb the stratum corneum of porcine skin under indoor light. Chem Res Toxicol 26: $1579-1590$ 
Citation: Palmer BC, De Louise LA (2020) Morphology-Dependent Titanium Dioxide Nanoparticle-Induced Keratinocyte Toxicity and Exacerbation of Allergic Contact Dermatitis. J Toxicol Cur Res 4: 019.

17. Sayes CM, Wahi R, Kurian PA, Liu Y, West JL, et al. (2006) Correlating nanoscale titania structure with toxicity: A cytotoxicity and inflammatory response study with human dermal fibroblasts and human lung epithelial cells. Toxicol Sci 92: 174-185.

18. Xue C, Wu J, Lan F, Liu W, Yang X, et al. (2010) Nano titanium dioxide induces the generation of ROS and potential damage in HaCaT cells under UVA irradiation. J Nanosci Nanotechnol 10: 8500-8507.

19. Yin JJ, Liu J, Ehrenshaft M, Roberts JE, Fu PP, et al. (2012) Phototoxicity of nano titanium dioxides in $\mathrm{HaCaT}$ keratinocytes--generation of reactive oxygen species and cell damage. Toxicol Appl Pharmacol 263: 81-88.

20. Horie, M, Sakiko S, Haruhisa K, Yosuke T, AyakoN, et al. (2016) Does photocatalytic activity of $\mathrm{TiO}_{2}$ nanoparticles correspond to photo-cytotoxicity? Cellular uptake of $\mathrm{TiO}_{2}$ nanoparticles is important in their photo-cytotoxicity. Toxicology mechanisms and methods 26: 284-294.

21. Xie G, Lu W, Lu D (2015) Penetration of titanium dioxide nanoparticles through slightly damaged skin in vitro and in vivo. J Appl Biomater Funct Mater 13: 356-361.

22. Adachi K, Yamada N, Yoshida Y, Yamamoto O (2013) Subchronic exposure of titanium dioxide nanoparticles to hairless rat skin. Exp Dermatol 22: $278-283$.

23. Adachi K, Yamada N, Yamamoto K, Yoshida Y, Yamamoto O (2010) In vivo effect of industrial titanium dioxide nanoparticles experimentally exposed to hairless rat skin. Nanotoxicology 4: 296-306.

24. Federman DG, Kirsner RS, Concato J (2014) Sunscreen counseling by US physicians. JAMA 312: 87-88.

25. Jatana S, Palmer BC, Phelan SJ, De Louise LA (2017) Immunomodulatory effects of nanoparticles on skin allergy. Sci Rep 7: 3979 .

26. Ravichandran S, Sullivan MA, Callahan LM, Bentley KL, DeLouise LA (2015) Development and characterization of antibody reagents for detecting nanoparticles. Nanoscale 7: 20042-20054.

27. Esser PR, Wölfle U, Dürr C, von Loewenich FD, Schempp CM, et al (2012) Contact sensitizers induce skin inflammation via ROS production and hyaluronic acid degradation. PloS one 7: 41340.

28. Honda T, Nakajima S, Egawa G, Ogasawara K, Malissen B, et al. (2010) Compensatory role of Langerhans cells and langerin-positive dermal dendritic cells in the sensitization phase of murine contact hypersensitivity. J Allergy Clin Immunol 125: 1154-1156.

29. Gros E, Novak N (2012) Cutaneous dendritic cells in allergic inflammation. Clinical and Experimental Allergy 42: 1161-1175.

30. Weber FC, Németh T, Csepregi JZ, Dudeck A, Roers A, et al. (2015) Neutrophils are required for both the sensitization and elicitation phase of contact hypersensitivity. J Exp Med 212: 15-22.

31. Otsuka A, Kabashima K (2015) Mast cells and basophils in cutaneous immune responses. Allergy 70: 131-140.

32. Honda T, Egawa G, Grabbe S, Kabashima K (2013) Update of immune events in the murine contact hypersensitivity model: Toward the understanding of allergic contact dermatitis. Journal of Investigative Dermatology 133: 303-315.
33. Vocanson M, Hennino A, Cluzel-Tailhardat M, Saint-Mezard P, Benetiere $\mathrm{J}$, et al. (2006) CD8+ T cells are effector cells of contact dermatitis to common skin allergens in mice. The Journal of investigative dermatology 126: $815-820$.

34. Vocanson M, Hennino A, Chavagnac C, Saint-Mezard P, Dubois B, et al. (2005) Contribution of $\mathrm{CD}_{4}(+)$ and $\mathrm{CD}_{8}(+)$ T-cells in contact hypersensitivity and allergic contact dermatitis. Expert Rev Clin Immunol 1: 75-86.

35. Martinez-Finley EJ, Gavin CE, Aschner M, Gunter TE (2013) Manganese neurotoxicity and the role of reactive oxygen species. Free Radic Biol Med 62: $65-75$

36. Watchmaker J, Collins R, Chaney K (2015) Allergic contact dermatitis to manganese in metallic implant. Dermatitis 26: 149-150.

37. Shallcross L, Ritchie S, Harberts E, Tammaro A, Gaitens J, et al. (2014) Manganese oxidation state as a cause of irritant patch test reactions. Dermatitis 25: 66-71.

38. Park YH, Jeong SH, Yi SM, Choi BH, Kim Y-R, et al. (2011) Analysis for the potential of polystyrene and $\mathrm{TiO}_{2}$ nanoparticles to induce skin irritation, phototoxicity, and sensitization. Toxicol In Vitro 25: 1863-1869.

39. Auttachoat W, McLoughlin CE, White KL, Smith MJ (2014) Route-dependent systemic and local immune effects following exposure to solutions prepared from titanium dioxide nanoparticles. J Immunotoxicol 11 : 273-282.

40. Smulders S, Golanski L, Smolders E, Vanoirbeek J, Hoet PH (2015) Nano- $\mathrm{TiO}_{2}$ modulates the dermal sensitization potency of dinitrochlorobenzene after topical exposure. Br J Dermatol 172: 392-399.

41. Hussain S, Smulders S, Vooght VD, Ectors B, Boland S, et al. (2012) Nano-titanium dioxide modulates the dermal sensitization potency of DNCB. Part Fibre Toxicol 9: 15

42. Yanagisawa R, Takano H, Inoue K-I, Koike E, Kamachi T, et al. (2009) Titanium dioxide nanoparticles aggravate atopic dermatitis-like skin lesions in NC/Nga mice. Exp Biol Med (Maywood) 234: 314-322.

43. Wu J, Liu W, Xue C, Zhou S, Lan F, et al. (2009) Toxicity and penetration of $\mathrm{TiO}_{2}$ nanoparticles in hairless mice and porcine skin after subchronic dermal exposure. Toxicol Lett 191: 1-8.

44. Proksch E, Brasch J (2012) Abnormal epidermal barrier in the pathogenesis of contact dermatitis. Clin Dermatol 30: 335-344.

45. Wei JCJ, Edwards GA, Martin DJ, Huang H, Crichton ML, et al. (2017) Allometric scaling of skin thickness, elasticity, viscoelasticity to mass for micro-medical device translation: from mice, rats, rabbits, pigs to humans. Sci Rep 7: 15885.

46. Monteiro-Riviere NA, Bristol DG, Manning TO, Rogers RA, Riviere JE (1990) Interspecies and interregional analysis of the comparative histologic thickness and laser doppler blood flow measurements at five cutaneous sites in nine species. The Journal of Investigative Dermatology 95: 582586

47. Palmer BC, Jatana S, Phelan-Dickinson SJ, DeLouise LA (2019) Amorphous silicon dioxide nanoparticles modulate immune responses in a model of allergic contact dermatitis. Sci Rep 9: 5085. 


\section{Supplementary Figures}

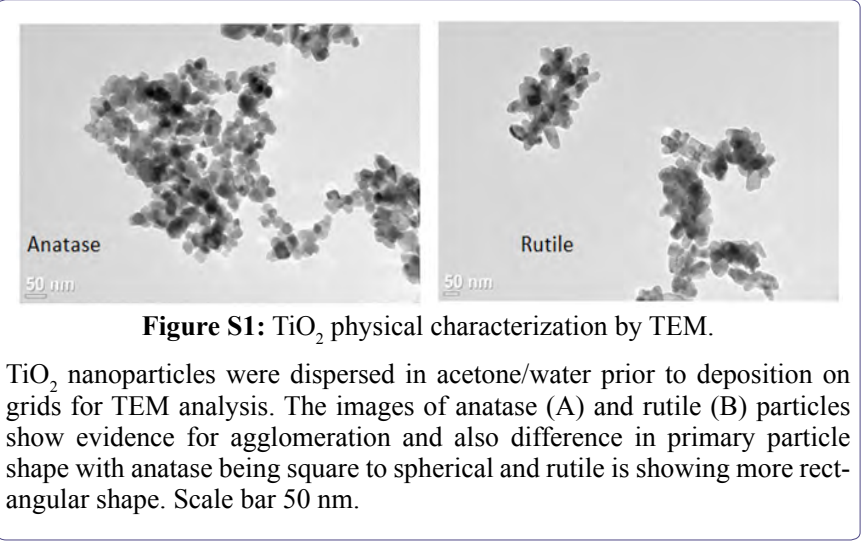

$\mathrm{TiO}_{2}$ nanoparticles were dispersed in acetone/water prior to deposition on grids for TEM analysis. The images of anatase (A) and rutile (B) particles show evidence for agglomeration and also difference in primary particle angular shape. Scale bar $50 \mathrm{~nm}$.

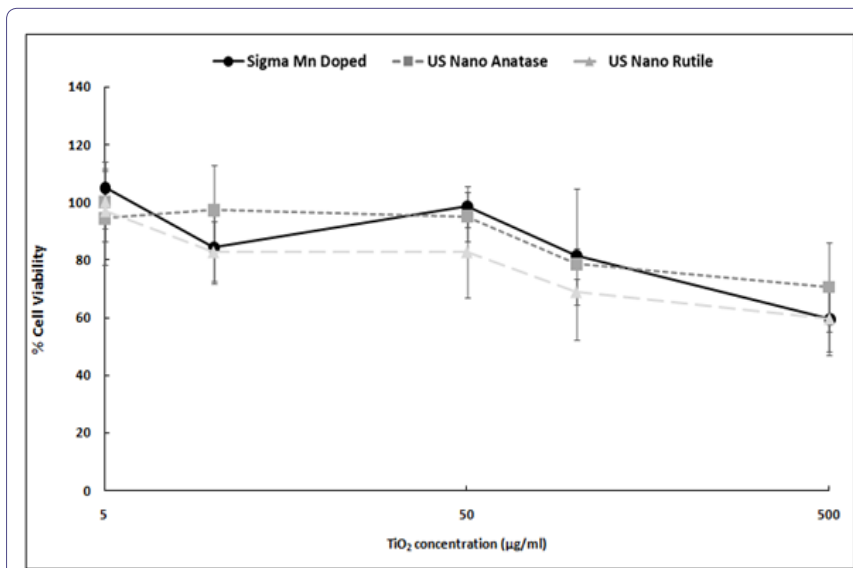

Figure S2: $\mathrm{TiO}_{2}$ induced keratinocyte cytotoxicity after 48 hours.

HaCaTs were exposed to $0,5,10,50,100$, or $500 \mu \mathrm{g} / \mathrm{mL}$ concentrations of anatase, rutile, or Sigma $\mathrm{Mn}$-doped $\mathrm{TiO}_{2}$ nanoparticles for 48 hours. Mild, dose-dependent decreases in cell viability were observed for all $\mathrm{TiO}_{2}$ particles tested (mean $\pm \mathrm{SD}, \mathrm{n}=3$ ). 


\section{di \\ неram}

Advances In Industrial Biotechnology | ISSN: 2639-5665

Advances In Microbiology Research | ISSN: 2689-694X

Archives Of Surgery And Surgical Education | ISSN: 2689-3126

Archives Of Urology

Archives Of Zoological Studies | ISSN: 2640-7779

Current Trends Medical And Biological Engineering

International Journal Of Case Reports And Therapeutic Studies | ISSN: 2689-310X

Journal Of Addiction \& Addictive Disorders | ISSN: 2578-7276

Journal Of Agronomy \& Agricultural Science | ISSN: 2689-8292

Journal Of AIDS Clinical Research \& STDs | ISSN: 2572-7370

Journal Of Alcoholism Drug Abuse \& Substance Dependence | ISSN: 2572-9594

Journal Of Allergy Disorders \& Therapy | ISSN: 2470-749X

Journal Of Alternative Complementary \& Integrative Medicine | ISSN: 2470-7562

Journal Of Alzheimers \& Neurodegenerative Diseases | ISSN: 2572-9608

Journal Of Anesthesia \& Clinical Care | ISSN: 2378-8879

Journal Of Angiology \& Vascular Surgery | ISSN: 2572-7397

Journal Of Animal Research \& Veterinary Science | ISSN: 2639-3751

Journal Of Aquaculture \& Fisheries | ISSN: 2576-5523

Journal Of Atmospheric \& Earth Sciences | ISSN: 2689-8780

Journal Of Biotech Research \& Biochemistry

Journal Of Brain \& Neuroscience Research

Journal Of Cancer Biology \& Treatment | ISSN: 2470-7546

Journal Of Cardiology Study \& Research | ISSN: 2640-768X

Journal Of Cell Biology \& Cell Metabolism | ISSN: 2381-1943

Journal Of Clinical Dermatology \& Therapy | ISSN: 2378-8771

Journal Of Clinical Immunology \& Immunotherapy | ISSN: 2378-8844

Journal Of Clinical Studies \& Medical Case Reports | ISSN: 2378-8801

Journal Of Community Medicine \& Public Health Care | ISSN: 2381-1978

Journal Of Cytology \& Tissue Biology | ISSN: 2378-9107

Journal Of Dairy Research \& Technology | ISSN: 2688-9315

Journal Of Dentistry Oral Health \& Cosmesis | ISSN: 2473-6783

Journal Of Diabetes \& Metabolic Disorders | ISSN: 2381-201X

Journal Of Emergency Medicine Trauma \& Surgical Care | ISSN: 2378-8798

Journal Of Environmental Science Current Research | ISSN: 2643-5020

Journal Of Food Science \& Nutrition | ISSN: 2470-1076

Journal Of Forensic Legal \& Investigative Sciences | ISSN: 2473-733X

Journal Of Gastroenterology \& Hepatology Research | ISSN: 2574-2566
Journal Of Genetics \& Genomic Sciences | ISSN: 2574-2485

Journal Of Gerontology \& Geriatric Medicine | ISSN: 2381-8662

Journal Of Hematology Blood Transfusion \& Disorders | ISSN: 2572-2999

Journal Of Hospice \& Palliative Medical Care

Journal Of Human Endocrinology | ISSN: 2572-9640

Journal Of Infectious \& Non Infectious Diseases | ISSN: 2381-8654

Journal Of Internal Medicine \& Primary Healthcare | ISSN: 2574-2493

Journal Of Light \& Laser Current Trends

Journal Of Medicine Study \& Research | ISSN: 2639-5657

Journal Of Modern Chemical Sciences

Journal Of Nanotechnology Nanomedicine \& Nanobiotechnology | ISSN: 2381-2044

Journal Of Neonatology \& Clinical Pediatrics | ISSN: 2378-878X

Journal Of Nephrology \& Renal Therapy | ISSN: 2473-7313

Journal Of Non Invasive Vascular Investigation | ISSN: 2572-7400

Journal Of Nuclear Medicine Radiology \& Radiation Therapy | ISSN: 2572-7419

Journal Of Obesity \& Weight Loss | ISSN: 2473-7372

Journal Of Ophthalmology \& Clinical Research | ISSN: 2378-8887

Journal Of Orthopedic Research \& Physiotherapy | ISSN: 2381-2052

Journal Of Otolaryngology Head \& Neck Surgery | ISSN: 2573-010X

Journal Of Pathology Clinical \& Medical Research

Journal Of Pharmacology Pharmaceutics \& Pharmacovigilance | ISSN: 2639-5649

Journal Of Physical Medicine Rehabilitation \& Disabilities | ISSN: 2381-8670

Journal Of Plant Science Current Research | ISSN: 2639-3743

Journal Of Practical \& Professional Nursing | ISSN: 2639-5681

Journal Of Protein Research \& Bioinformatics

Journal Of Psychiatry Depression \& Anxiety | ISSN: 2573-0150

Journal Of Pulmonary Medicine \& Respiratory Research | ISSN: 2573-0177

Journal Of Reproductive Medicine Gynaecology \& Obstetrics | ISSN: 2574-2574

Journal Of Stem Cells Research Development \& Therapy | ISSN: 2381-2060

Journal Of Surgery Current Trends \& Innovations | ISSN: 2578-7284

Journal Of Toxicology Current Research | ISSN: 2639-3735

Journal Of Translational Science And Research

Journal Of Vaccines Research \& Vaccination | ISSN: 2573-0193

Journal Of Virology \& Antivirals

Sports Medicine And Injury Care Journal | ISSN: 2689-8829

Trends In Anatomy \& Physiology | ISSN: 2640-7752

Submit Your Manuscript: https://www.heraldopenaccess.us/submit-manuscript 